\title{
INDIVIDUAL, SOCIAL, AND ENVIRONMENTAL RISK FACTORS OF MALARIA IN ROTE NDAO DISTRICT, EAST NUSA TENGGARA
}

\author{
Mat Yonathan Poy'), Hari Rarindo²), Sabina Gero3) \\ ${ }^{1)}$ District Health Office, Rote Ndao, East Nusa Tenggara \\ ${ }^{2)}$ Masters Program in Public Health, Universitas Nusa Cendana \\ 3) School of Health Polytechnics, Ministry of Health, Kupang
}

\begin{abstract}
Background: Malaria is one of the world's biggest killers. Studies into individual, social, and environmental risk factors of malaria in East Nusa Tenggara, Indonesia, are absent. This study aimed to investigate the individual, social, and environmental risk factors of malaria in East Nusa Tenggara, Indonesia.

Subjects and Method: This was a cross-sectional study conducted at Puskesmas Feapopi, Rote Ndao district, East Nusa Tenggara, Indonesia, from December 2015 to February 2016. A total sample of 310 subjects was selected for this study by multi stage random sampling. The dependent variable was malaria. The independent variables were mosquito repellent use, hanging out of the house in the evening, distance to a breeding place, type of house wall, distance to a stable, and health education on malaria. The data were collected by questionnaire, interview, and observation. Malaria was diagnosed microscopically. The data were analyzed by a multiple logistic regression.

Results: The risk of malaria increased with absence of mosquito repellent use $(\mathrm{OR}=4.61 ; 95 \% \mathrm{CI}=1.75$ to $12.16 ; \mathrm{p}=0.002)$, hanging out of the house in the evening $(\mathrm{OR}=5.67 ; 95 \% \mathrm{CI}=2.32$ to $13.82 ; \mathrm{p}<0.001)$, close to a breeding place $(\mathrm{OR}=3.54 ; 95 \% \mathrm{CI}=1.50$ to $8.33 ; \mathrm{p}=0.004)$, semi-permanent house wall $(\mathrm{OR}=$ 8.13; $95 \% \mathrm{CI}=2.99$ to $22.07 ; \mathrm{p}<0.001)$, far from a stable $(\mathrm{OR}=0.08 ; 95 \% \mathrm{CI}=0.03$ to $0.23 ; \mathrm{p}<0.001)$, and health education on malaria $(\mathrm{OR}=0.06 ; 95 \% \mathrm{CI}=0.03$ to $0.14 ; \mathrm{p}<0.001$ ).

Conclusion: The risk of malaria increases with absence of mosquito repellent use, hanging out of the house in the evening, close to a breeding place, semi-permanent house wall, far from a stable, and health education on malaria.
\end{abstract}

Keywords: individual, social, environment, risk factor, malaria.

Correspondence:

Mat Yonathan Poy. District Health Office, Rote Ndao, NTT-Indonesia.

Email: matpoy3084@gmail.com. Mobile: 082237263885.

The 4th International Conference on Public Health

Best Western Premier Hotel, Solo, Indonesia, August 29-30, 2018 | 41

https://doi.org/10.26911/theicph.2018.01.02 